\title{
MODEL FIELD STUDY OF SUMITHION 50 EC AND FUSILADE S ON PHEASANTS
}

\author{
L. VÁRNAGY ${ }^{1}$, P. BUdAI $^{1}$, Á. ZAJÁK $^{2}$, T. VARGA ${ }^{1}$ and E. MOLNÁR ${ }^{1}$ \\ ${ }^{1}$ Department of Hygiene, Institute of Plant Protection, Georgikon Faculty, \\ Pannon University of Agricultural Sciences, H-8361 Keszthely, P.O. Box 71, Hungary; \\ ${ }^{2}$ Ecotoxicological Laboratory, H-7136 Fácánkert, Hungary
}

(Received May 19, 1998; accepted September 30, 1998)

\begin{abstract}
Toxicological studies on wild animals play an important role in the ecotoxicological examination of pesticides. The applied model tests enable the assessment of toxicological consequences with particular regard to the life and nutrition of wild animals in the ploughed field among plants treated with pesticides. The application of different pesticide formulations on plough-land may pose a simultaneous chemical burden to wild birds. In this model study, manifestations of the interaction between an insecticide and a herbicide were studied in pheasants. The birds were placed on lucerne in cages $\left(48 \mathrm{~m}^{2}\right)$ and sprayed once. The applied doses were: Sumithion 50 EC 1 litre/ha + Fusilade S 6 litres/ha (practical doses) and Sumithion 50 EC 5 litres/ha + Fusilade S 30 litres/ha. The analytically determined pesticide concentration of the lucerne was taken as a basis in the further treatment of fodder. The fodder of pheasants contained the following chemicals: $85 \mathrm{mg} / \mathrm{kg}$ Sumithion $50 \mathrm{EC}+510 \mathrm{mg} / \mathrm{kg}$ Fusilade $\mathrm{S}$ and $425 \mathrm{mg} / \mathrm{kg}$ Sumithion $50 \mathrm{EC}+2250 \mathrm{mg} / \mathrm{kg}$ Fusilade S. Sporadic deaths observed among the pheasants were of traumatic origin and not due to a toxic effect. The decrease of body weight was significant only at the higher dose levels. Acetylcholinesterase (AChE) activity of the blood decreased significantly in both dose groups. On the basis of the results obtained it can be established that at the dose level used in the practice the pesticides studied do not give rise to a toxic interaction in pheasants.
\end{abstract} cal study

Key words: Pesticide, Sumithion 50 EC, Fusilade S, pheasant, toxicologi-

Over the last four decades the range and use of chemicals have increased all over the world. There are approximately 12 million registered preparations in the different countries. The chemicalisation of agriculture has resulted in an increased application of fertilisers, pesticides and other chemicals.

Ecotoxicological studies of environmental contaminants including pesticides have great importance. For environmental toxicity studies avian test models are preferred because birds are abundant, highly visible, have diverse behavioural patterns, and can frequently be studied both in the laboratory and in their natural environment. Pheasants, which are game birds important in Hun- 
gary, are exposed to the effect of pesticides during the laying and hatching period because the field use of plant-protective chemicals coincides with their reproductive phase.

In Hungary, the toxicological screening methods of the pesticide registration procedure have included the bird (pheasant or wild-duck) model field study since 1988 (Várnagy, 1989). These experimental results enable the assessment or determination of $(i)$ the direct or indirect toxic effects of pesticide formulations on birds, including their reproductive toxicity; (ii) the clinical symptoms, pathomorphological consequences, analytical and clinical chemistry data; (iii) the preventive measures necessary for protecting wild birds on plough-land.

The objective of the experiment reported here was to obtain basic toxicological data on two pesticides applied in combination in avian species. The toxic interactions of these formulations have been studied in an earlier teratogenicity trial (Varga et al., 1997).

\section{Materials and methods}

Sumithion 50 EC (active ingredient: 50\% fenitrothion) and Fusilade S (active ingredient: $12.5 \%$ fluazifop-P-butyl) were used in combination on lucerne. Spraying doses: 1 litre/ha Sumithion 50 EC +6 litres/ha Fusilade S (I) (these doses correspond to dose levels used in the plant protection practice), and 5 litres/ha Sumithion 50 EC + 30 litres/ha Fusilade S (II).

Birds: Phasianus colchicus mongolicus et torquatus; age: 12-14 months; sex: 50\% male and 50\% female; body weight: 1095-1385 g (male) and 948$1295 \mathrm{~g}$ (female). The experimental groups were formed at random. A total of 27 cocks and 27 hens were used, while 3 cocks and 3 hens served as reserve. The pheasants were marked individually with a metal ring.

Three groups were used (a control and two dose levels). Each group included 9 cocks and 9 hens. Before the start of the experiment an adaptation period of 8 days was allowed, when the birds were kept under the same circumstances ( 3 cocks and 3 hens in a cage).

The pheasants were placed into cages $\left(16 \mathrm{~m}^{2} \times 2 \mathrm{~m}\right)$ which contained hiding places $\left(1 \mathrm{~m}^{2}\right)$. The minimum-maximum temperatures $\left({ }^{\circ} \mathrm{C}\right)$, the relative humidity (\%) of the air, and the quantity of rainfall were measured daily. Light conditions: natural photoperiod (15-16 h/day).

The feed of the birds was sprayed lucerne and additional standard fodder $a d$ libitum. As drinking water, tap-water was provided ad libitum and changed daily.

The applied pesticide concentrations and the concentration stability and homogeneity of test materials in the fodder were determined by a gas-liquid chromatographic (GLC) method using a Packard 428 type apparatus in a preliminary study. The detection limit was $0.1 \mathrm{mg} / \mathrm{kg}$, using NP-selective ther- 
moionic detector (Ambrus, 1981). On the basis of the analytically measured residue levels on lucerne, the calculated concentrations of experimental agents in the feed preparation were (i) $85 \mathrm{mg} / \mathrm{kg}$ Sumithion $50 \mathrm{EC}+510 \mathrm{mg} / \mathrm{kg}$ Fusilade S; (ii) $425 \mathrm{mg} / \mathrm{kg}$ Sumithion $50 \mathrm{EC}+2250 \mathrm{mg} / \mathrm{kg}$ Fusilade $\mathrm{S}$.

In the main experiment the feed was withdrawn for $4 \mathrm{~h}$, then the pheasants were placed onto the fresh-flowering, 15-20 cm high lucerne, and spraying was applied on that field. Further $48 \mathrm{~m}^{2}$ areas of lucerne were sprayed with pesticides in order to transfer the pheasants onto fresh lucerne after 7 days. The birds were also fed an additional fodder during the 14-day period of exposure. The postobservation phase lasted from Day 14 to Day 28 of the experiment, when the pheasants were fed normal (untreated) lucerne and fodder.

Observations: The pheasants were observed for clinical symptoms once a day while mortality was recorded occasionally. Feed consumption and body weight were determined and recorded once a week.

Pathological examination: Necropsy was performed after death, on Day 7 of the trial (four aggressive cocks), and at the end of the trial (for all the survivors).

On Day 3 of the trial, acetylcholinesterase enzyme activity of the whole blood was measured by a clinico-chemical method (National Institute for Labour and Industrial Hygiene, 1981) using blood samples taken from the v. axillaris. Detection limit of the method: a $\mathrm{pH}$ difference of 0.1 .

Individual body weight data were evaluated by Student's $t$-test (Finney, 1972). The EPA guidelines $(1978,1982)$ were followed during this experiment.

\section{Results}

The analytical data obtained by GLC had verified the homogeneity and stability of pesticide concentrations in the milled fodder. The recovery rate of the active ingredients was 93.2 and $98.8 \%$, respectively.

No toxicity symptoms were observed during the experiment. Pheasants that sustained accidental traumatic injuries were ataxic.

Only the group exposed to the higher dose level showed a significant decrease in body weight during the period of exposure (Tables 2 and 3). The feed consumption data are summarised in Table 4. The average values of Group II showed a decrease with respect to the control.

The cumulative mortality data are presented in Table 1 . No death due to the toxic effect of pesticides was recorded. Six pheasants died during the experiment because of large traumatic injuries. 
Table 1

Cumulative mortality data in the model field study of Sumithion 50 EC and Fusilade S applied in combination

\begin{tabular}{cccccccccccccccc}
\hline \multirow{2}{*}{$\begin{array}{c}\text { Dose } \\
\text { groups }\end{array}$} & \multicolumn{1}{c}{} & 1 & 2 & 3 & 4 & 5 & 6 & 7 & 8 & 9 & 10 & 11 & 12 & \multicolumn{1}{c}{ Mortality rate } \\
$(\%)$ & 13 & 14 \\
\hline \multirow{2}{*}{$\mathrm{C}$} & $0 / 18$ & $1 / 18$ & $1 / 18$ & $1 / 18$ & $1 / 18$ & $1 / 18$ & $1 / 18$ & $1 / 18$ & $1 / 18$ & $1 / 18$ & $1 / 18$ & $1 / 18$ & $1 / 18$ & $1 / 18$ \\
I & $0 / 18$ & $0 / 18$ & $0 / 18$ & $1 / 18$ & $2 / 18$ & $2 / 18$ & $2 / 18$ & $2 / 18$ & $2 / 18$ & $2 / 18$ & $2 / 18$ & $2 / 18$ & $2 / 18$ & $2 / 18$ \\
II & $0 / 18$ & $0 / 18$ & $0 / 18$ & $0 / 18$ & $1 / 18$ & $1 / 18$ & $2 / 18$ & $3 / 18$ & $3 / 18$ & $3 / 18$ & $3 / 18$ & $3 / 18$ & $3 / 18$ & $3 / 18$ & 11.1 \\
\end{tabular}

$\mathrm{C}=$ untreated control; I = 1 litre/ha Sumithion $50 \mathrm{EC}+6$ litres/ha Fusilade S; II = 5 litres/ha Sumithion $50 \mathrm{EC}+30$ litres/ha Fusilade S

Table 2

Average body weight of pheasants in the model field study of Sumithion 50 EC and Fusilade S applied in combination

\begin{tabular}{|c|c|c|c|c|c|c|}
\hline \multirow{2}{*}{$\begin{array}{l}\text { Dose } \\
\text { groups }\end{array}$} & \multicolumn{6}{|c|}{ Average body weight (g) on days } \\
\hline & -8 & 0 & 7 & 14 & 21 & 28 \\
\hline \multicolumn{7}{|l|}{$\mathbf{C}$} \\
\hline cocks & $1241 \pm 72.7$ & $1201 \pm 68.4$ & $1211 \pm 59.7$ & $1203 \pm 59.5$ & $1230 \pm 59.5$ & $1224 \pm 66.3$ \\
\hline hens & $1094 \pm 104.9$ & $1081 \pm 87.3$ & $1057 \pm 44.8$ & $1025 \pm 57.3$ & $1008 \pm 76.0$ & $969 \pm 61.3$ \\
\hline \multicolumn{7}{|l|}{ I } \\
\hline cocks & $1253 \pm 65.9$ & $1261 \pm 62.5$ & $1255 \pm 87.4$ & $1321 \pm 52.2$ & $1346 \pm 69.6$ & $1352 \pm 59.9$ \\
\hline hens & $1088 \pm 105.2$ & $1037 \pm 102.4$ & $1016 \pm 115.0$ & $990 \pm 69.2$ & $993 \pm 54.2$ & $967 \pm 53.4$ \\
\hline \multicolumn{7}{|l|}{ II } \\
\hline cocks & $1231 \pm 86.6$ & $1251 \pm 81.4$ & $1111 \pm 56.2$ & $1132 \pm 29.0$ & $1240 \pm 32.9$ & $1252 \pm 37.6$ \\
\hline hens & $1099 \pm 123.0$ & $1056 \pm 95.9$ & $956 \pm 85.5$ & $924 \pm 61.9$ & $962 \pm 67.0$ & $958 \pm 53.5$ \\
\hline
\end{tabular}

$\mathrm{C}=$ untreated control; I = 1 litre/ha Sumithion $50 \mathrm{EC}+6$ litres/ha Fusilade S; II = 5 litres/ha Sumithion 50 EC + 30 litres/ha Fusilade S 
Table 3

Changes in body weight $(\mathrm{g})$ in the model field study of Sumithion $50 \mathrm{EC}$ and Fusilade $\mathrm{S}$ after combined administration (mean \pm S.D.)

\begin{tabular}{|c|c|c|c|c|c|}
\hline \multirow{3}{*}{ Dose groups } & \multicolumn{5}{|c|}{ Changes in body weight (g) } \\
\hline & \multirow{2}{*}{$\begin{array}{c}\text { Adaptation } \\
\text { Day }-8 \text { to Day } 0\end{array}$} & \multicolumn{2}{|c|}{ Exposure } & \multicolumn{2}{|c|}{ Observation } \\
\hline & & Day 7 & Day 14 & Day 21 & Day 28 \\
\hline \multicolumn{6}{|l|}{ C } \\
\hline cocks & $-40 \pm 42.8$ & $-5 \pm 19.7$ & $3 \pm 11.1$ & $27 \pm 1.7$ & $-6 \pm 7.0$ \\
\hline hens & $-13 \pm 68.2$ & $24 \pm 56.2$ & $-33 \pm 40.8$ & $-16 \pm 40.4$ & $-42 \pm 6.0$ \\
\hline \multicolumn{6}{|l|}{ I } \\
\hline cocks & $8 \pm 47.5$ & $-2 \pm 30.2$ & $0 \pm 0.0$ & $25 \pm 19.4$ & $6 \pm 15.3$ \\
\hline hens & $-51 \pm 43.4$ & $-21 \pm 75.0$ & $-53 \pm 51.1$ & $3 \pm 25.3$ & $-26 \pm 24.9$ \\
\hline \multicolumn{6}{|l|}{ II } \\
\hline cocks & $20 \pm 62.1$ & $-139^{\mathrm{b}} \pm 29.2$ & $-25^{\mathrm{a}} \pm 33.0$ & $108 \pm 40.6$ & $12 \pm 19.2$ \\
\hline hens & $-43 \pm 34.9$ & $-100^{\mathrm{a}} \pm 59.4$ & $-32^{c} \pm 50.6$ & $38 \pm 15.7$ & $4 \pm 20.2$ \\
\hline
\end{tabular}

$\mathrm{C}=$ untreated control; $\mathrm{I}=1$ litre/ha Sumithion $50 \mathrm{EC}+6$ litres/ha Fusilade S; II = 5 litres/ha Sumithion $50 \mathrm{EC}+30$ litres/ha Fusilade $\mathrm{S} ;{ }^{\mathrm{a}}=\mathrm{P}<0.05 ;{ }^{\mathrm{b}}=\mathrm{P}<0.001 ;{ }^{\mathrm{c}}=\mathrm{P}<0.005$ compared to the control data

Table 4

Estimated feed consumption of pheasants in the model field study of Sumithion 50 EC and Fusilade S after combined administration (g/bird/day)

\begin{tabular}{|c|c|c|c|c|c|c|}
\hline \multirow{2}{*}{$\begin{array}{l}\text { Dose } \\
\text { groups }\end{array}$} & \multirow{2}{*}{$\begin{array}{l}\text { Cage } \\
\text { No. }\end{array}$} & \multirow{2}{*}{$\begin{array}{l}\text { Adaptation } \\
\text { period }\end{array}$} & \multicolumn{2}{|c|}{ Exposure } & \multicolumn{2}{|c|}{ Observation } \\
\hline & & & Day 7 & Day 14 & Day 21 & Day 28 \\
\hline \multirow[t]{4}{*}{$\mathbf{C}$} & 31 & 50 & 70 & 67 & 74 & 57 \\
\hline & 32 & 53 & 70 & 57 & 66 & 68 \\
\hline & 33 & 46 & 60 & 67 & 55 & 55 \\
\hline & average & 50 & 67 & 64 & 65 & 60 \\
\hline \multirow[t]{4}{*}{ I } & 21 & 74 & 68 & 65 & 99 & 61 \\
\hline & 22 & 63 & 58 & 42 & 67 & 53 \\
\hline & 23 & 51 & 68 & 74 & 81 & 64 \\
\hline & average & 63 & 65 & 60 & 82 & 59 \\
\hline \multirow[t]{4}{*}{ II } & 11 & 57 & 33 & 41 & 93 & 64 \\
\hline & 12 & 65 & 24 & 49 & 94 & 61 \\
\hline & 13 & 69 & 26 & 79 & 74 & 57 \\
\hline & average & 64 & 28 & 56 & 87 & 61 \\
\hline
\end{tabular}

$\mathrm{C}=$ untreated control; $\mathrm{I}=1$ litre/ha Sumithion $50 \mathrm{EC}+6$ litres/ha Fusilade S; II = 5 litres/ha Sumithion $50 \mathrm{EC}+30$ litres/ha Fusilade S 
On Day 7 of the experiment 4 cocks per dose were dissected, then at the end of the trial period all the birds were subjected to pathological examination. The pheasants were in good general condition. Kidney degeneration was found in one case while liver degeneration in six cases. These pathological changes were seen both in the control and in the treated groups. In a hen (dose II) egg retention in the uterus resulted in thickening of the oviduct wall.

Acetylcholinesterase enzyme activity of the blood significantly decreased $(\mathrm{P}<0.001)$ as a result of sublethal doses of Sumithion 50 EC and Fusilade S applied in combination (Table 5).

Table 5

Inhibition of acetylcholinesterase (AChE) activity in pheasant blood by Sumithion $50 \mathrm{EC}$ administered in combination with Fusilade S during the model field study

\begin{tabular}{lccc}
\hline & \multicolumn{3}{c}{ Dose groups } \\
\cline { 2 - 4 } & $\begin{array}{c}\mathrm{C} \\
\mathrm{n}=6\end{array}$ & $\begin{array}{c}\mathrm{I} \\
\mathrm{n}=6\end{array}$ & $\begin{array}{c}\mathrm{II} \\
\mathrm{n}=6\end{array}$ \\
\hline Changes of $\mathrm{pH}$ values (\%)/time unit & 0.0 & $84.9^{\mathrm{a}}$ & $96.2^{\mathrm{a}}$ \\
\hline
\end{tabular}

$\mathrm{C}=$ untreated control; $\mathrm{I}=1$ litre/ha Sumithion $50 \mathrm{EC}+6$ litres/ha Fusilade S; II = 5 litres/ha Sumithion $50 \mathrm{EC}+30$ litres/ha Fusilade $\mathrm{S} ;{ }^{\mathrm{a}}=$ significant decrease $\mathrm{P}<0.001$ compared to the control data; $\mathrm{n}=$ number of samples

\section{Discussion}

The pesticides of Sumithion $50 \mathrm{EC}$ and Fusilade S (insecticide and herbicide) were sprayed in combination on lucerne during the model field study on pheasants. The birds were fed an additional experimental fodder in which the concentrations of pesticides were the same as on the lucerne.

No toxic clinical signs were seen. The treatments did not cause toxicity and no deaths were found among the pheasants due to pesticide application. The pathological changes seen were not related to the treatments.

The acetylcholinesterase enzyme activity showed dose-dependent changes because of the application of Sumithion $50 \mathrm{EC}$ of anticholinesterase effect.

At dose level II body weight and feed consumption simultaneously decreased. The probability of a 5-fold exposure to pesticides is very low in the natural environment. On the basis of the feed refusal seen at dose level II, it appears that pheasants refuse to consume plants exposed to pesticides (Sumithion $50 \mathrm{EC}$ and Fusilade $\mathrm{S}$ ) and look for other, non-contaminated sources of food.

It can be established that Sumithion 50 EC and Fusilade $\mathrm{S}$ applied in combination at dose levels normally used in plant protection practice (1 litre/ha Sumithion 50 EC and 6 litres/ha Fusilade S) caused no detectable interactive toxicity in pheasants under the conditions of this model field study. 


\section{Acknowledgement}

This work was supported by a grant from the Hungarian Scientific Research Fund (OTKA), project No. T 012728.

\section{References}

Ambrus, Á. (1981): General method for determination of pesticide residues in samples of plant origin, soil and water. J. Ass. Off. Anal. Chem. 3, 733-768.

EPA (1978 and 1982): EPA Pesticide Assessment Guidelines - Subdivision E, Hazard Evaluation: Wildlife and Aquatic Organisms 71-5.

Finney, D. J. (1972): An Introduction to Statistical Science in Agriculture. Blackwell Sci. Publ., Oxford.

National Institute for Labour and Industrial Hygiene (1981): Methodological Guidelines (in Hungarian). Országos Munka- és Üzemegészségügyi Intézet, Budapest, pp. 184-185.

Varga, T., Hlubik, I., Budai, P., Molnár, E. and Várnagy, L. (1997): Individual and combined toxicity of Sumithion $50 \mathrm{EC}$ and Fusilade $\mathrm{S}$ on pheasant embryos. Med. Fac. Landbouww. Univ. Gent 62/2a, 259-264.

Várnagy, L. (1989): Toxicological investigations of agricultural chemical substances during the approbation process (in Hungarian, with English abstract). Magyar Állatorvosok Lapja 44, 313-314. 
